This article was downloaded by: [Australian National University Library]

On: 15 April 2010

Access details: Access Details: [subscription number 907447645]

Publisher Routledge

Informa Ltd Registered in England and Wales Registered Number: 1072954 Registered office: Mortimer House, 3741 Mortimer Street, London W1T 3JH, UK

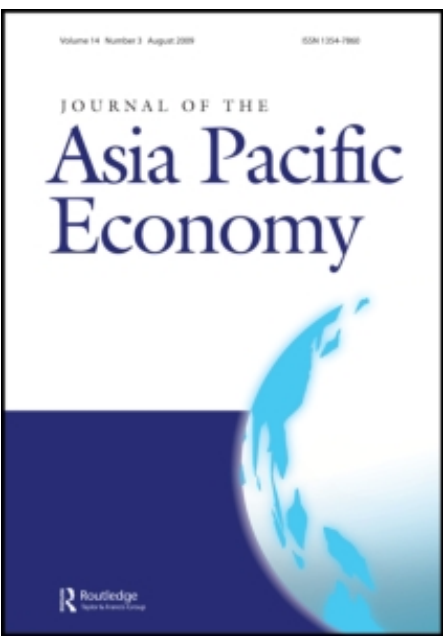

\title{
Journal of the Asia Pacific Economy
}

Publication details, including instructions for authors and subscription information:

http://www.informaworld.com/smpp/title content=t713703356

\section{Measuring Good Governance Using Time Series Data: Fiji Islands}

Azmat Gani ${ }^{\text {a }}$ :Ron Duncan ${ }^{\text {b }}$

a School of Economics, Faculty of Business and Economics, The University of the South Pacific, Fiji ${ }^{b}$

Pacific Institute of Advanced Studies in Development and Governance, The University of the South

Pacific, Suva, Fiji

To cite this Article Gani, Azmat andDuncan, Ron(2007) 'Measuring Good Governance Using Time Series Data: Fiji Islands', Journal of the Asia Pacific Economy, 12: 3, 367 - 385

To link to this Article: DOI: $10.1080 / 13547860701405979$

URL: http://dx.doi.org/10.1080/13547860701405979

\section{PLEASE SCROLL DOWN FOR ARTICLE}

Full terms and conditions of use: http://www.informaworld.com/terms-and-conditions-of-access.pdf

This article may be used for research, teaching and private study purposes. Any substantial or systematic reproduction, re-distribution, re-selling, loan or sub-licensing, systematic supply or distribution in any form to anyone is expressly forbidden.

The publisher does not give any warranty express or implied or make any representation that the contents will be complete or accurate or up to date. The accuracy of any instructions, formulae and drug doses should be independently verified with primary sources. The publisher shall not be liable for any loss, actions, claims, proceedings, demand or costs or damages whatsoever or howsoever caused arising directly or indirectly in connection with or arising out of the use of this material. 


\title{
Measuring Good Governance Using Time Series Data: Fiji Islands
}

\author{
AZMAT GANI* \& RON DUNCAN** \\ *School of Economics, Faculty of Business and Economics, The University of the South Pacific, Fiji \\ ** Pacific Institute of Advanced Studies in Development and Governance, The University of the South \\ Pacific, Suva, Fiji
}

\begin{abstract}
This paper reports on the construction of a governance index for Fiji Islands for the period 1985 to 2003. The governance index has three core dimensions, each a composite of several indicators. Time series for each of the three dimensions of governance, as well as for the overall governance index, are presented in a range from zero (poorest achievement) to 1.0 (best achievement). The indices indicate that Fiji's governance performance was very adversely affected by the coups of 1987 and 2000, with the Rule of Law dimension being the most adversely affected. The index constructed provides a basis from which to monitor future governance performance.
\end{abstract}

KEY WoRDS: Fiji, governance, dimensions, measurement, bureaucracy

\section{Introduction}

An index of governance performance for Fiji has been developed using mostly published time-series data for the period 1985 to 2003. The composite index of governance, which is measured over the range from zero to 1.0, is based on three core dimensions: the rule of law, government effectiveness and regulatory quality, all widely believed to reflect governance performance. The numerical index allows for a temporal comparison of achievements across the dimensions of governance.

Similar to the definition of governance of Neumayer (2002) and Polidano (2000), Kaufmann et al. (2003) note that the definition and measurement of governance indicators has been primarily concerned with three activities:

- the process by which governments are selected and replaced;

- the capacity of the government to effectively formulate and implement sound policies; and

- the respect of citizens and the state for the institutions that govern economic and social interactions among them.

Correspondence Address: Azmat Gani, School of Economics, Faculty of Business and Economics, The University of the South Pacific, Fiji, PO Box 1168, Suva, Fiji. E-mail: gani_a@usp.ac.fj

ISSN 1354-7860 Print/1469-9648 Online /07/030367-19 @ 2007 Taylor \& Francis DOI: $10.1080 / 13547860701405979$ 


\section{A. Gani \& R. Duncan}

This paper draws on these broad definitions of governance in selecting the variables to be included in the governance index for Fiji.

There has been a large amount of activity in measuring aspects of governance in recent years, which has involved international institutions as well as non-governmental bodies, including the World Bank's Index of State Credibility (World Bank, 1997), the joint OECD, UN and World Bank's Participatory Development and Good Governance (OECD Development Assistance Committee, 1998), Transparency International's Corruption Perception Index, the Institute for Management Development's Competitiveness Rankings, the International Country Risk Guides (2002), the Freedom House (2002) Civil Liberties and Political Rights, and the Heritage Foundation's (2002) Index of Economic Freedom. For the most part, these indicators of governance are based upon peoples' perceptions of governance performance in various areas. The perceptions have been derived from surveys, polls, or expert opinion. Perhaps the most widely quoted governance indicators, based on perceptions derived in these ways, are those developed for 199 countries (for the years 1996, 1998, 2000 and 2002) by Kaufmann et al. $(2003,2004)$ of the World Bank. The authors acknowledge the limitations of their indicators due to the unreliability of the polls or survey results, and note that 'the margins of error associated with the governance indicators remain large relative to the units in which governance is measured.'

An alternative to the use of such 'soft' qualitative information is to use 'hard' information, i.e. quantitative data drawn from official publications. The absence of governance indicators based on quantitative information has motivated us to develop governance indicators for Fiji using mostly published data that is made available on a regular basis. The governance indicators constructed in this way can be relatively easily updated on an annual basis without incurring high costs, as opposed to information obtained through surveys and polls. Further, governance indicators based on annual data can provide governments with regular updates on the quality of their governance. The decision to construct governance indicators in this way was made not only because of the arbitrary nature of qualitative information derived from surveys and expert opinions but also because of the high cost of carrying out such surveys on a regular basis in a small country like Fiji. Moreover, obtaining a sufficient number of expert opinions on small countries would usually be difficult.

Achieving and maintaining good governance and strong institutions is an issue concerning many countries; indeed it has become a focal point for the countries of the Pacific region and their development assistance partners, given their poor economic and social progress (Hughes, 2003; Duncan \& Chand, 2002; Duncan, 2004). Saldanha (2004) has argued that governance problems in the Pacific find their roots deeply embedded in political and social issues, such as the structures of government, the quality of leadership, and the capacity of civil society to hold government accountable. In response to these concerns, the leaders of the Pacific Islands Forum countries have set achieving good governance as one of the four priority goals in the development of the Pacific Plan for the closer integration of the region. 
Fiji has been no exception in respect of poor economic and social progress and concerns about good governance since gaining independence from the United Kingdom in 1970 (Prasad, 2003). The general election of 1987 led to Fiji's first political crisis with the overthrow of the democratically elected government by the Fiji military. The events of 1987 led to continuing political instability, resulting in falling investment, sluggish economic growth, slow progress with economic reforms, and deteriorating institutional infrastructure. In 2000, a democratically elected government was again removed from office and held hostage for 56 days, this time by armed civilians (Gani, 2005). Despite the restoration of an elected government, threats of military intervention have continued. Given these circumstances and the ongoing attempts by the government, development partners, and civil society to improve governance, it appears highly desirable to be able to monitor the outcomes of their efforts.

The structure of the paper is as follows. The next section presents a brief literature review of the development of governance indicators. The selection of core governance dimensions, sub-dimensions, and potential indicators of each of the sub-dimensions are described in the third section. In the fourth section, the technique employed in construction of the governance indicators is presented. The choice of variables and the sources of data are discussed in the fifth section. The resulting governance indicators are presented in the sixth section, while the limitations of the indicators are highlighted in the seventh section. Conclusions follow in the final section.

\section{Literature Review}

A recent development within the economics profession is the emergence of the socalled new institutional economics - a body of analysis generally identified as an attempt to extend the range of neoclassical theory by highlighting the importance of institutions that are fundamental to the effective functioning of market-based economies, such as law and order, property rights, contracts, and governance structures (Rutherford, 2001). Institutions can be thought of as the 'set of rules' that determine the behaviour of individuals within society. The role of institutions in the process of economic growth has long been emphasised by Douglass North, the Nobel prize-winning economic historian (North, 1990). Governance can be seen as the outcome of the effectiveness of a society's institutions. If the institutions are appropriate and effective, the outcome should be good governance (Duncan, 2003).

As Duncan (2003) has argued, the role of institutions is still not incorporated formally into the economic theory of growth; therefore, nor is the role of governance. At this time there is a developing body of empirically established associations between institutions and economic growth and between what are believed to be measures of governance and economic performance (see for example, Knack, 2001; Rutherford, 2001; Kaufmann et al., 2004). However, empirical associations between variables are not the same as tests of hypotheses, which can only be developed from within a theoretical framework. At this stage, therefore, the development of governance 
indicators does not have a theoretical basis. All that we have is a developing consensus about the kinds of economic management and other government performance-related variables that indicate the quality of governance in a country. If governance is an outcome of the appropriateness and effectiveness of a country's institutions (formal and informal), governance indicators can be seen as indicators of the quality of a country's institutions.

While developmental thinking is still heavily dependent on neo-classical models focusing on physical and human capital within a stable macroeconomic environment, changes are taking place. Besley \& Burgess (2003) argue that greater emphasis on institutional reforms to expand household opportunities, improve the business environment, and enhance accountability of elected officials are important in reducing poverty and achieving higher growth levels. This conclusion is supported by Barro (2001) who carried out a study of over 100 countries, which confirmed that an increase in the rule of law has a positive and statistically significant effect on growth, while the study by Chong \& Calderon (2000) provides empirical support for the idea that poor institutions are associated with income inequality in poor countries.

In their analysis of the regulation of entry, Djankov et al. (2002) found that heavy regulation of firms is associated with less democratic government, greater corruption, and larger unofficial economies. Regulatory intrusion into enterprise activities may be manifested in a variety of forms: permits and licenses, arbitrary taxation, and superfluous statutes (see for example, Safavian et al., 2001). Fischer et al. (2001) in their assessment of the Palestinian economy over the period 1994 to 2000 show that excessive red tape, bureaucratic inefficiency, and perceptions of poor governance and financial mismanagement deterred domestic and foreign investors. Gausch \& Hahn (1997) note that, 'the overall lesson is not that regulation is generally undesirable, but that it often has undesirable economic consequences'.

\section{The Choice of Governance Dimensions}

Given that governance outcomes are widespread and varied, we have chosen governance dimensions that largely reflect the definitions of governance as proposed by Kaufmann et al. (1999, 2003), Polidano (2000) and Neumayer (2002). Using these definitions as a guide, three core governance dimensions were formulated: the rule of law, government effectiveness and regulatory quality. Each of the three dimensions of governance has sub-dimensions; and indicator variables that are believed to directly or indirectly capture or reflect these sub-dimensions of governance are used in their measurement.

As stated previously, the governance index developed here is mostly based on hard data and so the choice of core dimensions, sub-dimensions and variables is dictated largely by the regular availability of data. While arguments may be made for other indicators of governance, they would be of no use if appropriate data were unavailable. Developing countries generally have poor statistical records, and the 
area of government accountability is no exception. For example, Bardhan (2002) notes that the information and accounting systems and the mechanisms for monitoring public services are much weaker in low-income countries. Our search for government accountability data shows that Fiji is no exception. Thus, achieving a good balance between the availability of data and the desirable measures to include is a difficult task.

Justification for the selection of governance dimensions, sub-dimensions and indicators used in the construction of the governance indicator for Fiji is provided in the sub-sections that follow (see Duncan et al., 2004 for a fuller discussion of the choice of these variables).

\section{The Rule of Law}

The rule of law dimension addresses the interactions between citizens and the institutions that assist in governing these interactions and is comprised of four subdimensions: political freedom, political stability, judicial effectiveness and media independence. Several indicators were chosen to capture each of the four subdimensions (Table 1).

Political freedom is an important aspect of human welfare and reflects the extent to which the rule of law is observed. Van Den Berg (2001) argues that:

personal freedom to make choices is not only important for innovation and economic growth but also good governance and the freedom to choose not only has a direct effect on people's happiness but enhances long-term economic capacity to provide people with greater material wealth.

The rule of law can also be influenced by political instability through its impact on state institutions. Political instability may mean that the governing regime is vulnerable and this may prevent the emergence of strong governing institutions, for example, the judiciary. In such circumstances, the government may be inclined to support institutions such as the military to strengthen its hold on power, which could lead to financial and human resources being diverted from non-military to military functions and undermine institutions that support good governance.

The quality and independence of the media can also influence the rule of law. Pande (2003) observes that 'a basic premise of representative democracy is that all those subject to policy should have a voice in its making.' Thus, civic involvement in government through newspapers, television, radio, telephone, and the internet can have an important bearing on government responsibility. Unelected community organisations also become involved in the scrutiny of government through the media and thus strengthen the accountability of governments (Bardhan, 2002). A free media allows people to voice their concerns about government actions and influence government performance, and even have the government removed. Djankov et al. (2002) confirms that state ownership of the media is, on the whole, negatively correlated with good 


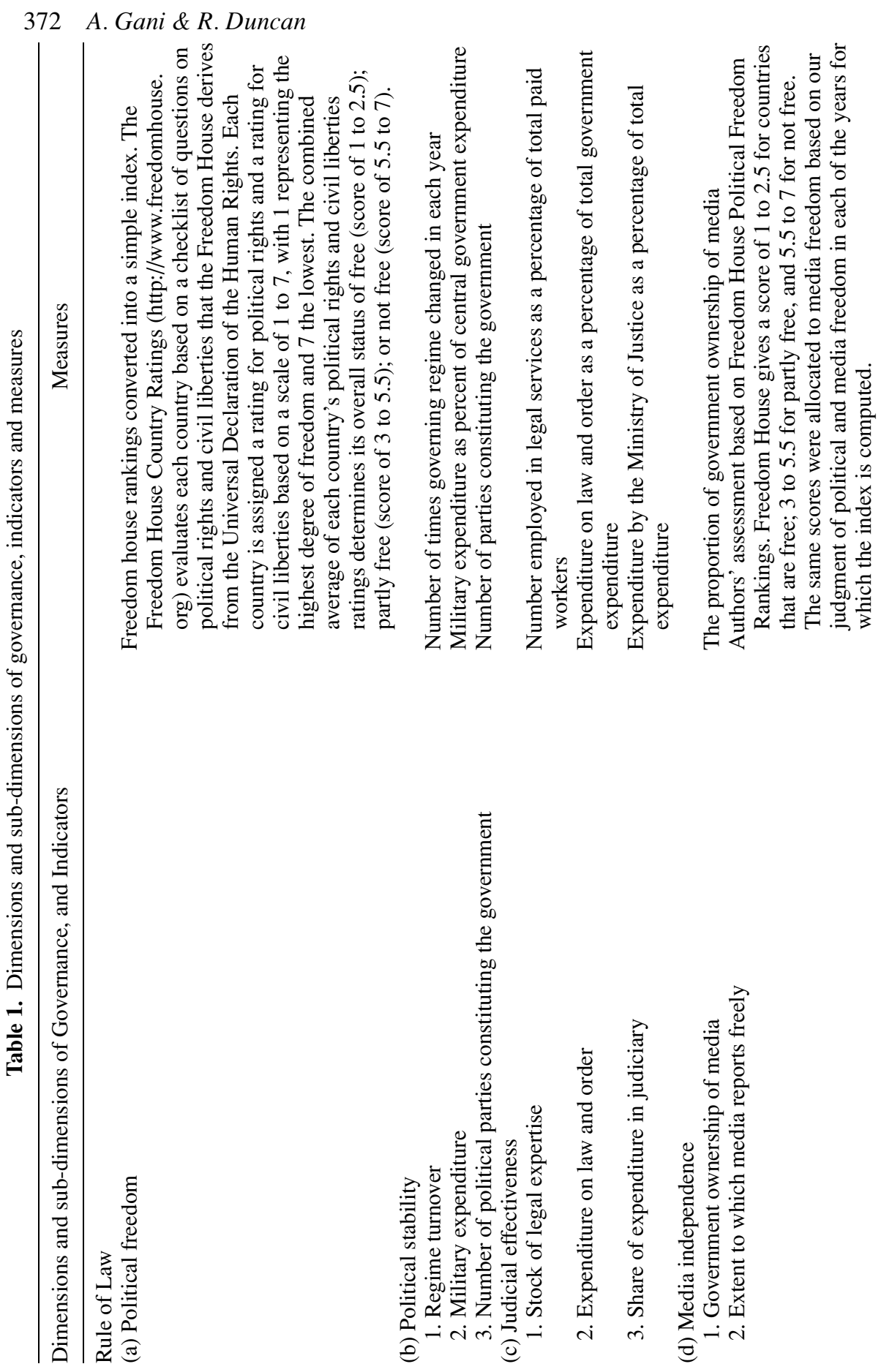



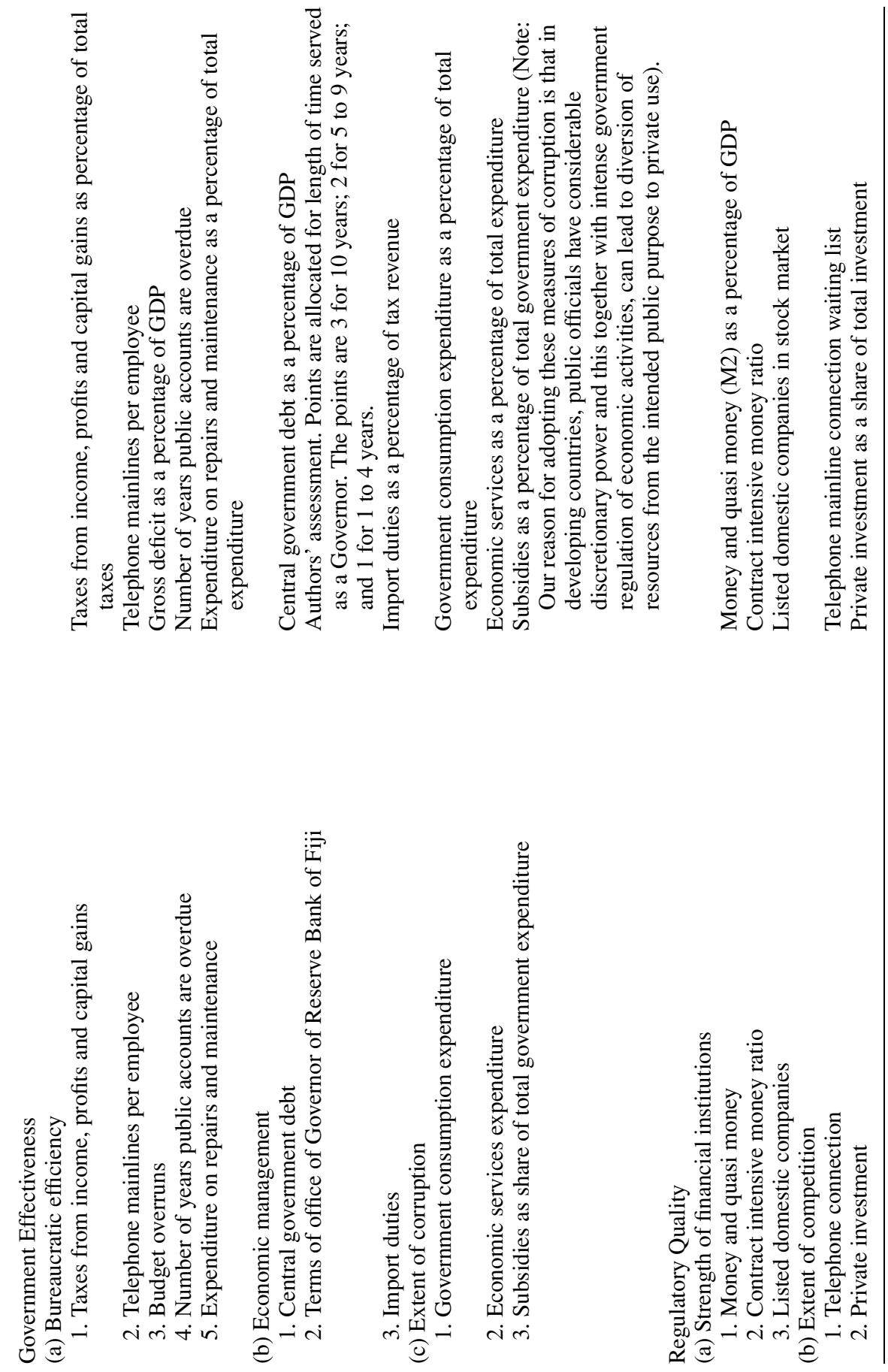


\section{A. Gani \& R. Duncan}

government; while more freedom of the press through private ownership tends to shorten political tenure.

The judiciary is an important institution in facilitating sound and fair observance of the rule of law. National progress extends beyond investment in capital and a stable macroeconomic environment to the protection of property. Of equal importance are the maintenance of law and order, limitations on government power to interfere in the people's activities, and a fair and predictable legal system. Van Den Berg (2001) argues that in countries where property rights are clearly defined and strictly enforced, crime will seldom pay. Hence, rational people are more likely to engage in productive activity than theft. In their assessment of the Palestinian economy, Fischer et al. (2001) contended that laws, once prepared, needed to be adopted more quickly; and once approved, they should be implemented forcefully to ensure a level playing-field, protect property rights and encourage competition.

\section{Government Effectiveness}

The government effectiveness dimension captures the ability to develop and implement sound policies, efficiently deliver public goods and services, and enforce rules uniformly. Three sub-dimensions were chosen to reflect this aspect of governance: bureaucratic efficiency, economic management, and corruption (see Table 1).

Government plays a major role in most economies. Other than its taxing and spending functions, its roles extend to the establishment of property rights, police protection units, the judiciary, national defence, regulation of market activity, and so on. Bureaucratic efficiency in these areas can promote speedy progress in nation building and improvement in the welfare of society. If public officials are allowed to exert discretionary power over economic affairs, they can divert resources from the intended public purpose to private use (Romer, 1998). Thus, government with its extraordinary powers, with police and/or army enforcement, often damages human welfare intentionally (Van Den Berg, 2001).

Economic management is an essential responsibility of government and can be considered from the comparative advantage perspective as proposed by Krueger (1990):

Government is a non-market organization, and generally, it must do things on a large scale. It follows that activities such as the maintenance of law and order (especially enforcement of contracts), provision of information and provision of basic services which are inherently large scale in scope (roads and communications) are those in which the government is at no disadvantage in providing services on a large scale and where private agents may face a disadvantage in attempting to do so. Thus, the frequent government failures in developing economies are a result of the violation of the comparative advantage principle. 
Subsidies, regulations, and direct participation in economic activity are some of the violations leading to government failure due to the absence of mechanisms that cause government to behave in accordance with social costs and benefits.

The presence of corruption in the public sector can negatively affect government effectiveness. The abuse of public power for private benefit can arise as a result of intense governmental regulation of many economic activities: price ceilings or floors, quantitative restrictions on imports, regulations about types of workers to hire, etc. Further, the complexity of taxation and other laws may allow scope for evasion or for the exercise of rent seeking by public officials. Safavian et al. (2001) argue that because heavy regulatory intrusion results in considerable time spent with officials, coupled with attempts to evade taxation and other repressive regulations, firms and/or individuals often bribe public officials. Studies provide evidence that corruption is linked to the loss of foreign investment (Wei, 1997), the sustained existence of inefficient state-owned enterprises (Claessons \& Djankov, 1998), wage differentials between public employees (Banerjee, 1997), and poverty and income inequality (Van Rijakejhem \& Weder, 1997).

\section{Regulatory Quality}

Regulatory quality refers to the extent to which government policies promote or inhibit market activity and is measured here by two sub-dimensions: the strength of financial institutions and the extent of competition. Safavian et al. (2001) argue that regulatory intrusion into enterprise activities may be manifested in a variety of forms: obstacles to entry (permits and licenses); repressive, unpredictable and arbitrary taxation; required compliance with wide-ranging, superfluous statutes and regulations; and significant statutory power given to regulatory officials charged with monitoring and enforcing compliance among firms. Regulations that are costly to firms or people can induce bribes or other lobbying activities to bring about changes or, at least, waivers of the regulations in question. Regulatory intrusion is notable for its various negative effects including less democratic government, corruption, and development of informal activity (Djankov et al., 2002); deterrence of domestic and foreign investors (Fischer et al., 2001); and overall undesirable economic consequences (Gausch \& Hahn, 1997).

\section{Statistical Framework}

Before the governance indices were computed, achievement in each of the subdimensions of the above three dimensions was measured numerically within the range zero to 1.0. The interpretation of the sub-indices and the overall governance index, which is an arithmetical average of the sub-indices, is that a value closer to zero indicates a lower level of achievement. Since our governance indicators utilise annual time series data, expressing the governance index within the range of zero to 1.0 for each year allows policy makers to easily follow the trends in measures of governance. 
Twenty-five variables (see Table 1) were chosen as direct measures or proxies for the sub-dimensions. As noted above, the selection of the indicators was dictated by the availability of quantitative information. Once data was collected for each indicator, it was expressed in index form.

In order to compute the indicators for each of the three dimensions, 'benchmark values' (BMVs), indicating the minimum and maximum attainable numerical values for each of the indicators, were established. To the best of our knowledge, past studies measuring good governance have not made use of the benchmarking concept. One argument for using the BMVs is that comparisons of governance performance with similar economies are useful in exerting peer pressure, while comparisons with economies with higher levels of achievements in governance can show where to head in future, or what realistic governance targets can be set. In his assessment of the 'competitiveness index' of the World Economic Forum (2000), Lall (2001) noted that the competitiveness index was flawed not only because of drawbacks in its methodology but also because there is a strongly felt need for benchmarking national competitive capabilities. He argued that it is important that the World Economic Forum improve its product and methodology. Lall (2001) also noted that benchmarking national economies is now an important tool for policy making.

Recent literature shows evidence of use of the benchmark concept. While its application is currently confined to non-governance measures, it is worth mentioning these studies to provide justification for our use of the BMV. UNCTAD's (2002) Inward FDI Potential Index uses minimum and maximum values of each of the eight key FDI determinants in computing the index. The most recent use of benchmarking is in the construction of The ARCO Technology Index, developed by Archibugi \& Coco (2004). These authors devised an index of technological capabilities that includes three main components: creation of technology, the technological infrastructures, and the development of human skills. In order to allow for time-series comparisons, Archibugi \& Coco employ maximum and minimum values for the sub-indicators of the ARCO.

Establishing the BMVs for our governance measures was a difficult task. The most appropriate procedure would be to refer to a sample of countries that are high achievers in terms of good governance. This would give an indication of the minimum and maximum achievements for each dimension in relation to the best performers. The difficulty lies in the choice of countries. The high-income countries have a record of more effective governance than the lower-income and less-advanced countries. Therefore, the high-income countries could form the benchmark. However, linking Fijian indicators of governance to the high-income countries is unsatisfactory because the minimum scores of the high-income countries in many cases exceed the maximum scores attained in Fiji. Fiji is ranked as a lower-middle-income country with possibly less well-developed institutions. Thus, it may be more appropriate to choose BMVs from among the lower-middle-income countries. However, due to the absence of published data for several of the indicators chosen, this approach is also problematic. Hence, for the present it was decided to restrict selection to Fijian BMVs, 
Table 2. BMVs for the rule of law

\begin{tabular}{|c|c|c|c|}
\hline Dimension & $\begin{array}{l}\text { Sub-dimensions } \\
\text { and measures }\end{array}$ & $\begin{array}{l}\text { BMV Minimum } \\
\text { attainable }\end{array}$ & $\begin{array}{l}\text { BMV Maximum } \\
\text { attainable }\end{array}$ \\
\hline \multirow[t]{12}{*}{ Rule of Law } & (a) Political freedom & 1 & 5.5 \\
\hline & (b) Political stability & & \\
\hline & 1. Regime turnover & 0.0 & 2.0 \\
\hline & 2. Military expenditure & 3.7 & 8.8 \\
\hline & $\begin{array}{l}\text { 3. Number of parties } \\
\text { constituting government }\end{array}$ & 1.0 & 3.0 \\
\hline & (c) Judicial effectiveness & & \\
\hline & $\begin{array}{l}\text { 1. Court officials' } \\
\text { qualifications }\end{array}$ & 0.133 & 0.693 \\
\hline & $\begin{array}{l}\text { 2. Expenditure on law and } \\
\text { order }\end{array}$ & 3.630 & 5.654 \\
\hline & $\begin{array}{l}\text { 3. Share of expenditure on the } \\
\text { judiciary }\end{array}$ & 0.211 & 0.850 \\
\hline & (d) Media independence & & \\
\hline & $\begin{array}{l}\text { 1. Government ownership of } \\
\text { media }\end{array}$ & 25.0 & 34.38 \\
\hline & $\begin{array}{l}\text { 2. Extent to which media } \\
\text { reports freely }\end{array}$ & 2.0 & 6.0 \\
\hline
\end{tabular}

the local best practice, and revise these BMVs once lower-middle-income countries measures become available. This means selecting the minimum and maximum attainable achievements for each of the indicators over the sample period. These values are reported in Tables 2 to 4. It should be noted that the BMVs reported in Tables 2 to 4 only indicates local best practice. As noted above, deficiencies with data for comparator countries (lower-middle-income country averages) do not allow us to use the Fiji data for comparisons with other countries. However, our intention is to update the results once comparator country BMVs become available. Given the methodology involved, updating the results will not be a difficult task. One possible advantage of the data presented in Tables 2 to 4 is that it may be used by other Pacific Island countries to benchmark their governance measures, given the common institutional features of a number of Pacific Island countries.

The achievements in each indicator for the three core dimensions are expressed using the following formula:

$$
S D I I_{t}=\frac{A I V_{t}-B M V_{t}^{\min }}{B M V_{t}^{\max }-B M V_{t}^{\min }}
$$

where,

$S D I I=$ sub-dimension indicator index,

$A I V=$ actual indicator value 
Table 3. BMVs for government effectiveness

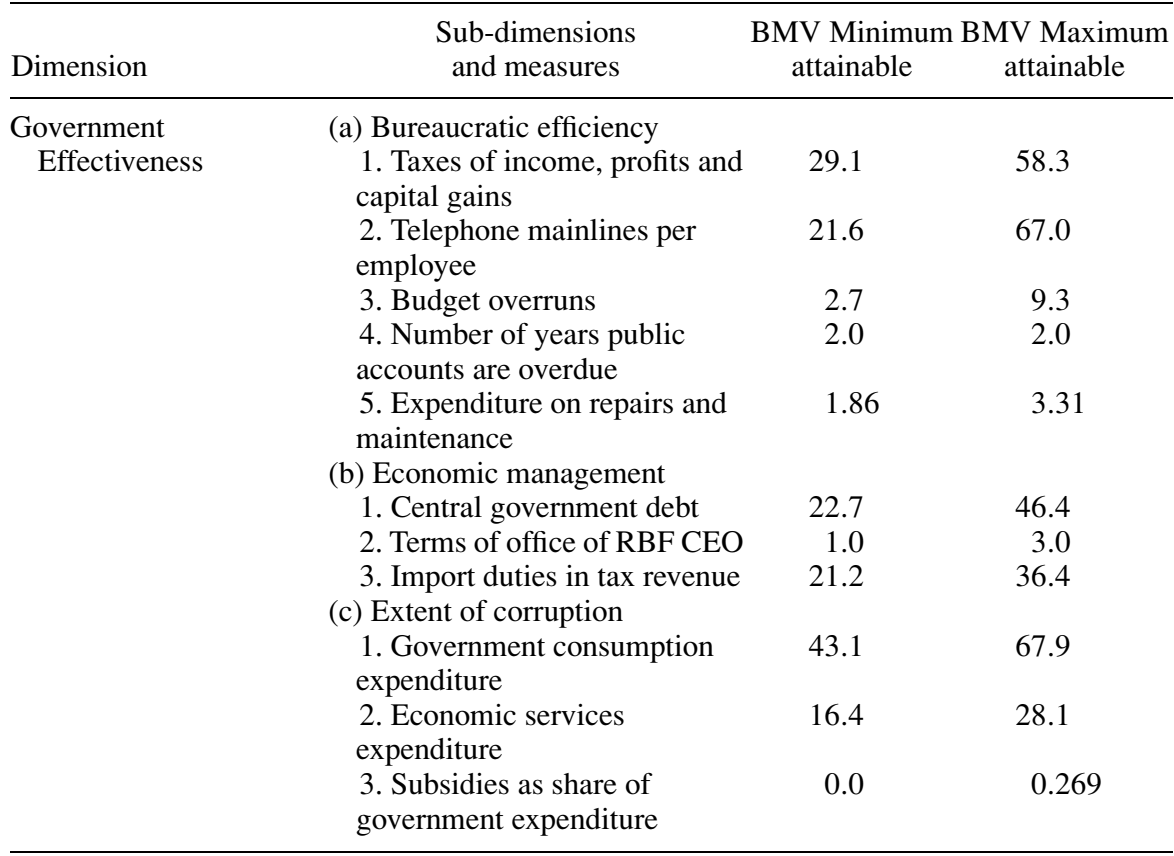

$$
\begin{aligned}
B M V^{\min } & =\text { benchmark minimum value }, \\
B M V^{\max } & =\text { benchmark maximum value, } \\
t & =\text { year. }
\end{aligned}
$$

The sub-dimension indicator indices are expressed as an average to form the subdimension index. The governance index $(G I)$ is the simple average of the three core dimension indices: $G I=[1 / 3(D 1+D 2+D 3)]$ where D1 to D3 are the three core dimensions.

\section{Indicators and Data}

Previous estimations of governance indicators have not made much use of quantitative data, probably because of its unavailability, the time-consuming nature of collection, and the often-aggregate nature of quantitative information. Further, the lack of published data that can capture the intangible dimensions of governance has likely constrained its use. However, a search for quantitative data to capture the various elements of governance may be useful. We have attempted to do this because 
Table 4. BMVs for regulatory quality

\begin{tabular}{llcc}
\hline Dimension & \multicolumn{1}{c}{$\begin{array}{c}\text { Sub-dimensions } \\
\text { and measures }\end{array}$} & $\begin{array}{c}\text { BMV Minimum } \\
\text { attainable }\end{array}$ & $\begin{array}{c}\text { BMV Maximum } \\
\text { attainable }\end{array}$ \\
\hline Regulatory Quality & $\begin{array}{l}\text { (a) Strength of financial } \\
\text { institutions } \\
\text { 1. Money and quasi } \\
\text { money }\end{array}$ & 36.4 & 52.6 \\
$\begin{array}{l}\text { 2. Contract intensive } \\
\text { money ratio } \\
\text { 3. Listed domestic } \\
\text { companies }\end{array}$ & 78.53 & 92.24 \\
(b) Extent of \\
competition \\
$\begin{array}{l}\text { 1. Telephone mainline } \\
\text { connection waiting list } \\
\text { 2. Private investment }\end{array}$ & 215 & 15.0 \\
\hline
\end{tabular}

of the arbitrary nature of qualitative information and the limitations on the use of surveys and expert opinion in small countries.

For nearly all sub-dimensions of governance, several indicators were selected that it was felt reflected achievement in that area. The exception was political freedom, which is a sub-dimension of the core dimension rule of law. In this case the Freedom House measure of political freedom in Fiji was taken as the sole measure of the sub-dimension.

For the sub-dimension political stability, three indicators were chosen: regime turnover, military expenditure, and number of parties constituting government. For the sub-dimension judicial effectiveness, three indicators were selected: stock of legal expertise, expenditure on law and order, and share of expenditure on the judiciary. Finally, for the sub-dimension media independence, the indicators chosen were government ownership of media and the extent to which the media reports freely.

The definitions of the sub-dimension indicators are shown in Table 1. The raw data were extracted from several publications: World Development Indicators CD ROM 2004 (World Bank, 2004); Key Economic Indicators (Asian Development Bank, 2003); Key Indicators (Fiji Bureau of Statistics, various issues); Quarterly Economic Bulletin (Reserve Bank of Fiji, various issues); Annual Employment Survey (Fiji Bureau of Statistics, 2001); Fiji Budget Estimates (Government of Fiji, various issues); Accounts and Finance (Parliament of Fiji, 2001); and Financial Statistics Yearbook (International Monetary Fund, 2003). Some information was also obtained through personal communication with the Fiji Electoral Office and Telecom Fiji. It is acknowledged that the selection of these indicators is arbitrary. Hopefully, they are not biased. Other quantitative indicators of these governance dimensions may be suggested and these can be tested. In future work, the statistical technique of principal 
Fiji's Governance Index

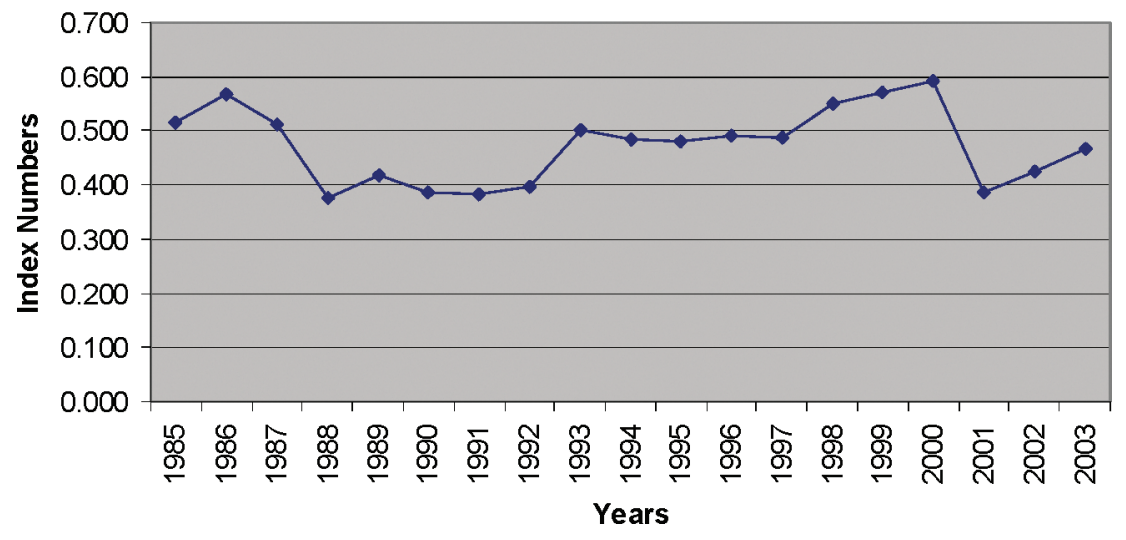

Figure 1. Fiji's governance index.

components may be applied to assess whether the various indicators are measuring the same variables or are adding information.

\section{Results}

The aggregate governance index for Fiji and for the three dimensions of governance for the period 1985 to 2002 are presented in Figure 1 and Table 5. Figure 1 depicts the trend in the aggregate governance index while Figures 2 to 4 depict trends in the core dimensions.

Figure 1 shows that the coups of 1987 and 2000 had a significant impact on governance so that despite periods of substantial improvement, the overall governance indicator was much the same at the end of the period as at the beginning. In 1986, prior to the first political crisis (1987), the governance index was 0.57 and then took a sharp dive to its lowest level for the whole period, reaching 0.32 in 1988 . As can be seen from Figure 2, the sharp decline in the rule of law was almost the sole contributor to this decline in the overall governance indicator. The modest decline in regulatory quality also contributed (Figure 3).

After 1987, Fiji's governance performance worsened, so that it took until 1993 to return to the 1987 level. During the 1988-94 period, the rule of law dimension continued to deteriorate, reaching a low of 0.21 in 1991 and then gradually improved. Over this same period, the other dimensions of governance followed different patterns. The government effectiveness dimension continued to improve from 1985 to 1990 , deteriorated between 1991 and 1992, and then peaked in 1998 (Figure 4). The regulatory quality dimension continued to improve from 1988 (0.44) until $2000(0.68)$. The sharp improvements in the rule of law and regulatory quality dimensions in 2000 
Table 5. Fiji’s Governance Indices, 1985 to 2003

\begin{tabular}{ccccc}
\hline Year & $\begin{array}{c}\text { Rule of } \\
\text { Law Index }\end{array}$ & $\begin{array}{c}\text { Government } \\
\text { Effectiveness Index }\end{array}$ & $\begin{array}{c}\text { Regulatory } \\
\text { Quality Index }\end{array}$ & $\begin{array}{c}\text { Overall Governance } \\
\text { Index }\end{array}$ \\
\hline 1985 & 0.841 & 0.300 & 0.403 & 0.514 \\
1986 & 0.859 & 0.401 & 0.443 & 0.568 \\
1987 & 0.660 & 0.417 & 0.454 & 0.510 \\
1988 & 0.263 & 0.427 & 0.437 & 0.316 \\
1989 & 0.401 & 0.490 & 0.359 & 0.417 \\
1990 & 0.210 & 0.530 & 0.424 & 0.388 \\
1991 & 0.208 & 0.503 & 0.439 & 0.383 \\
1992 & 0.279 & 0.403 & 0.512 & 0.398 \\
1993 & 0.534 & 0.433 & 0.534 & 0.500 \\
1994 & 0.492 & 0.442 & 0.516 & 0.483 \\
1995 & 0.420 & 0.497 & 0.519 & 0.429 \\
1996 & 0.439 & 0.478 & 0.552 & 0.489 \\
1997 & 0.430 & 0.501 & 0.527 & 0.486 \\
1998 & 0.468 & 0.650 & 0.534 & 0.551 \\
1999 & 0.495 & 0.674 & 0.541 & 0.570 \\
2000 & 0.662 & 0.427 & 0.684 & 0.591 \\
2001 & 0.331 & 0.389 & 0.442 & 0.387 \\
2002 & 0.530 & 0.273 & 0.473 & 0.425 \\
2003 & 0.517 & 0.357 & 0.562 & 0.466 \\
\hline
\end{tabular}

reflect well on the Indo-Fijian dominated government that held office for only one year before it was displaced in the 2000 coup.

The coup year 2000 also marked a turning point in Fijian governance. In that year the overall governance index was at its highest point and the rule of law, while still well below its pre-1987 level, was at its highest point since that time. Governance worsened

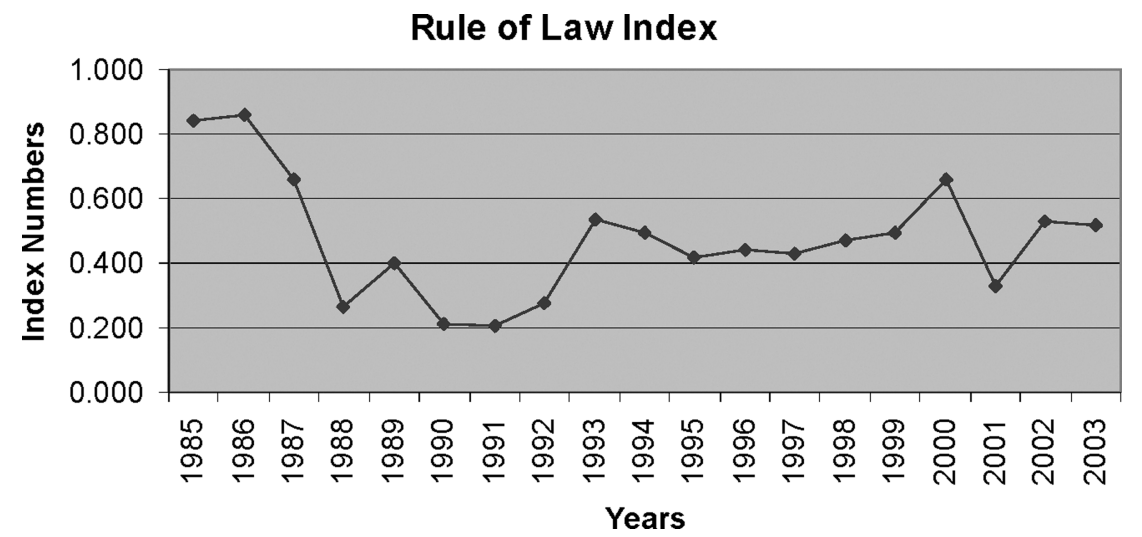

Figure 2. Rule of law index. 


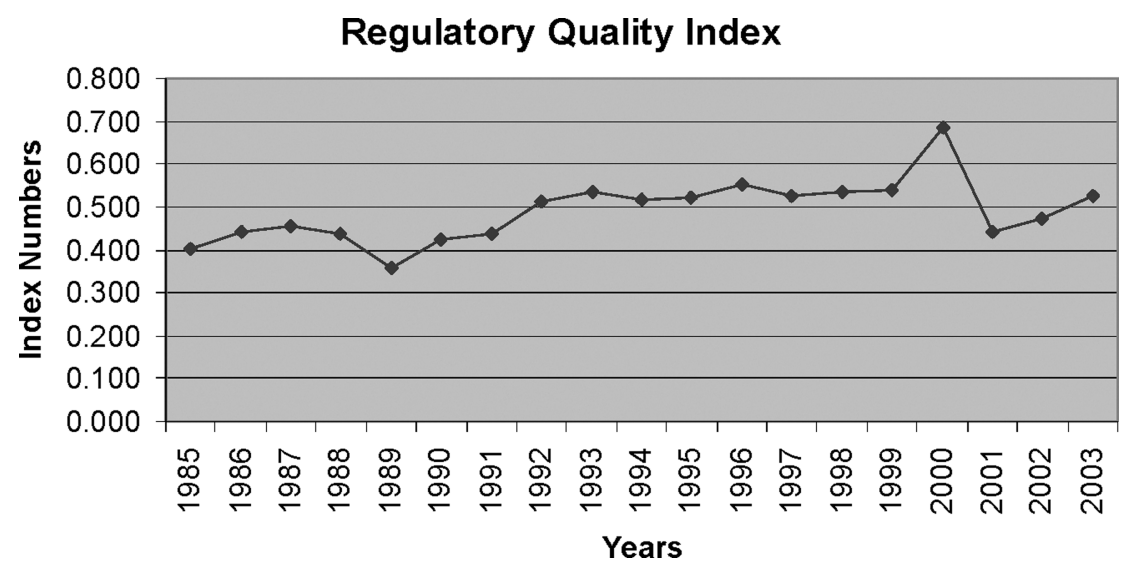

Figure 3. Regulatory quality index.

in 2001 , in the aftermath of the political crisis of 2000, reaching levels close to those of 1988, the year following Fiji's first political crisis. The regulatory quality index had reached 0.688 , as compared to 0.36 in 1989 . The government effectiveness dimension peaked in 1999 and continued to decline to be at its lowest level in 2002 for the whole of the sample period. However, there was an improvement in this dimension in 2003. While the rule of law and regulatory quality dimensions of governance deteriorated in 2001, they improved in 2002 and the regulatory quality index improved further in 2003. The improvements in the government effectiveness and regulatory quality dimensions in 2003 led to a slight improvement in the overall governance index in that year.

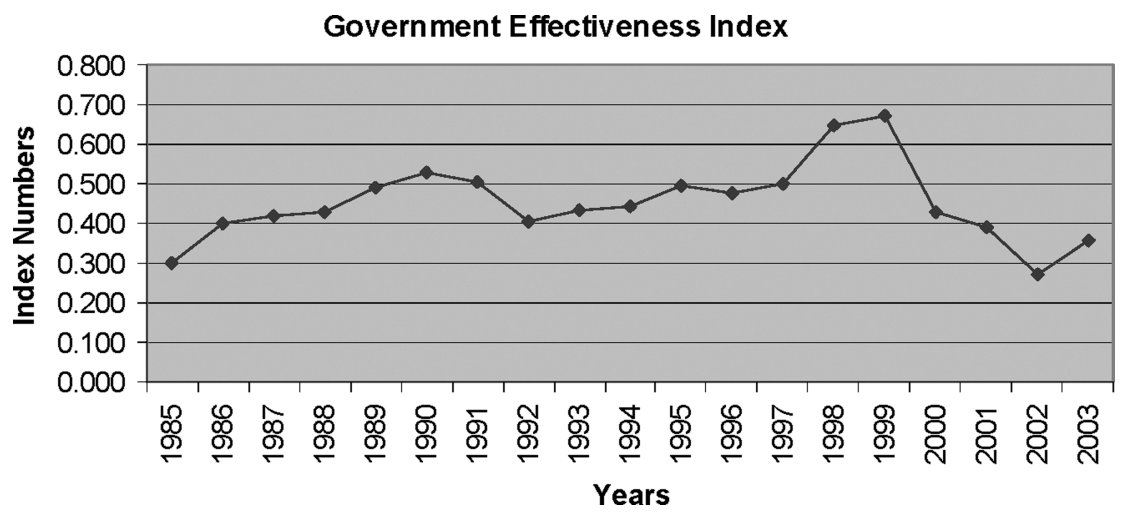

Figure 4. Government effectiveness index. 


\section{Limitations}

The governance index developed for Fiji has limitations to do with data and the choice of core dimensions, sub-dimensions, and indicators. The foremost limitation of the governance index is data and, as noted earlier, quantitative data are highly aggregate. Some of the measures of governance had to be captured using proxies or indirect measures and their ability to reflect accurately the governance attribute being measured may be suspect. The second major limitation is the choice of dimensions and indicators. Three core dimensions were chosen but this set is arbitrary. As previously mentioned, the choice of dimensions was largely dictated by the availability of hard data. Finally, there is the limitation of the choice of BMVs. These are restricted to Fiji, as comparator country measures were not available. This limitation can be reduced if, in future, measures for comparator countries become available.

\section{Conclusions}

The governance index developed for Fiji is made up of three core dimensions of governance, with each dimension comprised of several sub-dimensions. The overall governance index is based on 25 individual measures drawn from various sources for the period 1985 to 2003 . The limitations of the exercise in terms of choice of dimensions and sub-dimensions, which include the use of proxies as well as the quality of data, are noted.

Hopefully, the governance indicators provide government, policy makers, the private sector, society generally, and aid donors useful information by which to monitor changes in the quality of governance over time. The intention is to continue to modify and improve the indicators. Hopefully, with improved availability of data and more direct measures of governance dimensions, the index will gain greater precision.

There is no claim or guarantee that this index gives a complete picture of Fijian achievements in governance. There will always be disagreements over the definition of governance and which dimensions and indicators should be included. The important issue is whether the governance index reflects the quality of governance in a fair manner. We can observe, however, that the behaviour of the governance index and its components does appear to be consistent with the events that occurred in Fiji during the period concerned.

\section{Acknowledgment}

This research is supported by funding from the Australian Agency for International Development (AusAID) to the Governance Program of the University of the South Pacific. 


\section{A. Gani \& R. Duncan}

\section{References}

Archibugi, D. \& Coco, A. (2004) A new indicator of technological capabilities for developed and developing countries (ArCo), World Development, 32(4), pp. 629-654.

Asian Development Bank (2003) Key Economic Indicators. Available online at http://www.adb.org

Banerjee, A.V. (1997) A theory of misgovernance, Quarterly Journal of Economics, CXII, (4)4. pp. 1289332.

Bardhan, P. (2002) Decentralization of governance and development, Journal of Economic Perspectives, 16(4), pp. 185-205.

Barro, R.J. (2001) Human capital: growth, history and policy, The American Economic Review, 19(2), pp. $12-17$.

Besley, T. \& Burgess, R. (2003) Halving global poverty, Journal of Economic Perspectives, 17(3), pp. 3-22.

Blank, R.M. (2000) When can public policy makers rely on private markets? The effective provision of social services, The Economic Journal, 110(462), pp. C34-C49.

Burnside, C. \& Dollar, D.C. (1997) Aid policies and growth. Policy Research Working Paper 1777, Washington, DC, The World Bank.

Chong, A. \& Calderon, C. (2000) Institutional quality and income distribution, Economic Development and Cultural Change, 48(4), pp. 761-786.

Claessons, S. \& Djankov, S. (1998) Politicians and firms in seven Central and Eastern European Countries. World Bank Policy Research Working Paper 1954. Washington, DC, The World Bank.

Djankov, S., La Porta, R., Lopez-de-Silanes, F., \& Shleifer, A. (2002) The regulation of entry, Quarterly Journal of Economics, 117(1), pp. 1-37.

Duncan, R.C. \& Chand, S. (2002) Arc of instability, Asia Pacific Economic Literature, 16(1), pp. 111.

Duncan, R.C. (2003). Governance and growth. Paper presented to the Symposium on Governance held at the University of the South Pacific, Suva, September.

Duncan, R.C. (2004). The Fiji economy: needing a better investment environment. Paper presented to the 17th Australia Fiji Business Forum, 'Fiji and Australia New Partners', held by Australia Fiji Business Council at the Gold Coast, Australia, 17-19 October, 2004.

Duncan, Ron, Toatu, Teuea \& Gani, Azmat (2004) A conceptual framework for the development of composite governance indices for the Pacific Island countries. University of the South Pacific, Pacific Institute of Advanced Studies in Development and Governance, Governance Program Working Paper No. 1/2004. Available online at http://www.usp.ac.fj/index.php/piasdg.

Fiji Bureau of Statistics (2001) Annual Employment Survey. Suva.

Fiji Bureau of Statistics (Various issues) Key Indicators (Suva: Government of Fiji).

Fischer, S., Alonso-Gamo, P., \& Von Allmen, U.E. (2001) Economic developments in the West Bank and Gaza since OSLO, The Economic Journal, 111(472), pp. F254-F275.

Freedom House (2002) Annual Surveys of Freedom Country Ratings 1972-73 to 2001-02 (New York: Freedom House)

Gani, A. (2005). Fiji's emigrant transfers and potential macroeconomic effects, Pacific Economic Bulletin, 20(2), pp. 117-128.

Gausch, L. \& Hahn, R. W. (1997) The costs and benefits of regulation. Policy Research Working Paper No. 1773, World Bank, Washington DC.

Government of Fiji. (Various issues) Fiji Budget Estimates, Suva.

Heritage Foundation (2002) The Index of Economic Freedom (Washington, DC: The Heritage Foundation).

Hughes, H. (2003). Trade or aid? Which benefits developing countries most? Economic Papers, 22(3), pp. 20-34.

International Country Risk Guide (2002) The rating system. Available online at www://icrgonline.com.

International Monetary Fund (2003) Financial Statistics Yearbook (Washington, DC: IMF). 
Kaufmann, D., Kraay, A. \& Zoido-Lobaton, P. (1999) Aggregate governance indicators, Policy Research Working Paper 2195, Washington, DC, The World Bank.

Kaufmann, D., Kraay, A. \& Mastruzzi, M. (2003) Governance matters III: governance indicators for 1996-2002. Policy Research Working Paper No. 3106, The World Bank.

Kaufmann, D., Kraay, A. \& Mastruzzi, M. (2004) Governance matters III: Governance indicators for 1996, 1998, 2000, and 2002, The World Bank Economic Review, 18(2), pp. 253-287.

Knack, S. (2001) Aid dependence and the quality of governance: a cross-country empirical analysis, Southern Economic Journal, 68(2), pp. 310-329.

Krueger, A.O. (1990) Government failures in development, Journal of Economic Perspectives, 4(3), pp. 1617.

Lall, S. (2001) Competitiveness indices and developing countries: an economic evaluation of the Global Competitiveness Report, World Development, 29(9), pp. 1501-1525.

Neumayer, E. (2002) Is good governance rewarded? A cross-national analysis of debt forgiveness, World Development, 30(6), pp. 913-930.

North, D.C. (1990) Institutions, Institutional Change and Economic Performance (Cambridge: Cambridge University Press).

OECD Development Assistance Comittee (1998) Proposal for assessing progress in participatory development and good governance DCD/DAC (98) 7 (Paris: OECD).

Pande, R. (2003) Can mandated political representation increase policy influence for disadvantaged minorities? theory and evidence from India. The American Economic Review, 93(4), pp. 1132-1151.

Parliament of Fiji (2001) Accounts and Finance (Suva: Government of Fiji).

Polidano, C. (2000) Measuring public sector capacity, World Development, 28(5), pp. 805-822.

Prasad, B.C. (2003). Institutional economics and economic development-the theory of property rights, economic development, good governance and the environment, International Journal of Social Economics, 30(6), pp. 741-762.

Reserve Bank of Fiji (Various issues) Quarterly Economic Bulletin (Suva: Reserve Bank of Fiji).

Romer, P.M. (1998) Economic growth, in: David R. Henderson (ed.) The Fortune Encyclopedia of Economics (New York: Warner Books).

Rutherford, M. (2001) Institutional economics: then and now, Journal of Economic Perspectives, 15(3), pp. 173-194.

Safavian, M.S., Graham, D.H. \& Gonzalez-Vega, C. (2001) Corruption and microenterprises in Russia, World Development, 29(7), pp. 1215-1224.

Saldanha, C. (2004) Strategies for good governance in the Pacific, Asian-Pacific Economic Literature, 18(2), pp. 30-43.

UNCTAD. (2002) World Investment Report (New York: United Nations).

Van Den Berg, H. (2001) Economic Growth and Development (Boston: McGraw-Hill Irwin).

Van Rijckejhem, C. \& Weder, B. (1997) Corruption and the rate of temptations: do low wages in the civil service cause corruption? IMF Working Paper, International Monetary Fund: Washington, DC.

Wei, S.-J. (1997) Why is corruption so much more taxing than tax? Arbitrariness kills. National Bureau of Economic Research Working Paper No. W6255, Cambridge: NBER, November.

World Bank (1997) World Development Report-The State in a Changing World (New York: Oxford University Press).

World Bank (2004) World Development Indicators CD ROM (Washington, DC: World Bank).

World Economic Forum (2000) The Global Competitiveness Report 2000 (New York: Oxford University Press for World Economic Forum). 